\title{
David Oliver: Hotel chains are no answer to hospital bed crises
}

\section{David Oliver consultant in geriatrics and acute general medicine}

Berkshire

Roy Lilley, the ubiquitous health pundit, wrote in January of the need for radical solutions to current NHS crises rather than medical colleges endlessly campaigning for more resources. ${ }^{1}$

Lilley then set out some big, audacious ideas of his own. One was that, to "get the thousands [of people] marooned in hospital home safely," we should "Block-book Premier Inns; create step-down care. It's $£ 45$ a night. Include a matron and some care assistants and you'll do it for $£ 150$. Hospitals cost $£ 400 . " 2$

Does this idea bear scrutiny? Who are these patients stranded in hospital, and will it help them? ${ }^{34}$

Many are awaiting transfer to care homes. They are often still very unwell and dependent on care. Dementia, severe frailty, impaired continence, and mobility are the norm in long term care, along with multiple comorbidities. ${ }^{5}$ Median survival time from entering a UK nursing home is only nine months, so end of life care is key, and acute admissions to hospital are frequent. ${ }^{6}$ Are budget hotel chains geared up for such needs-even with care assistants?

Then we have those patients waiting for step-down intermediate care, whether at home or in community facilities. They aren't going for convalescence or a rest cure, but for rehabilitation requiring a skilled multidisciplinary approach. ${ }^{7}$ Without comprehensive assessment and rehabilitation, long term disability and dependence and the inability to return home are more likely. ${ }^{8}$

Packing patients off for a bed-to-chair existence, with no moving equipment or pressure relieving mattresses or physiotherapy, isn't the smartest move

We know that bed rest carries a whole range of harms and risks, especially for older, frailer people. ${ }^{9}$ Packing patients off for a bed-to-chair existence, with no moving or handling equipment or pressure relieving mattresses and no physiotherapy, isn't the smartest move. Soon we'd see "exit block" from the hotel too, when they were so dependent that no facility could take them.

In practice, patients on step-down hospital wards, in community hospitals, or in step-down beds in care homes still require skilled medical input-which is unsurprising in view of their medical complexity and risk of further deterioration.

Given the workforce and workload crises in general practice and community nursing, as well as struggles in providing clinical input to existing facilities, ${ }^{10}$ where would clinical input come from for patients decanted into budget hotels? We also have a national recruitment crisis among care assistants. ${ }^{112}$ Moving a few of them from home care to hastily commissioned hotel beds will solve nothing.

Lilley's idea doesn't stand up. Sometimes the radical idea was in fact the obvious one all along. We need to resource social and community health services properly to enable patients to leave hospital. And clinicians have a professional imperative to keep saying so, even if those such as Lilley might find it boring.

Competing interests: See www.bmj.com/about-bmj/freelancecontributors/david-oliver.

Provenance and peer review: Commissioned; not externally peer reviewed.

Follow David on Twitter, @mancunianmedic

1 Lilley R. NHS Managers blog: Define the future. 5 Jan 2017. Available at: www.spamdex org/nhsmanagers-net/333809-define-the-future.html.

Lilley R. NHS Managers blog: the people's business. 16 Jan 2017. Available at: http:// campaign.r20.constantcontact.com/render? $\mathrm{m}=1102665899193 \& \mathrm{ca}=\mathrm{a} 2337 \mathrm{e} 4 \mathrm{f}-\mathrm{ad} 84-48 \mathrm{e} 7$ b180-720595ec8413.

3 Oliver D. More older patients are stuck in hospitals. BMJ 2016;356:i2948. doi:10.1136/ bmi.i2948 pmid:27230037.

4 Edwards N. What's behind delayed transfers of care? Nuffield Trust. 8 Feb 2017. https:/ /www.nuffieldtrust.org.uk/resource/what-s-behind-delayed-transfers-of-care.

5 British Geriatrics Society. Commissioning guidance: high quality healthcare for care home residents. 2013. www.bgs.org.uk/campaigns/2013commissioning/Commissioning_2013. pdf.

6 Oliver D. Keeping care home residents out of hospital. BMJ 2016;356:i458.pmid:26813928.

7 NHS Benchmarking. National audit of intermediate care summary report. 2015. www. nhsbenchmarking.nhs.uk/CubeCore/.uploads/NAIC/Reports/ NAICReport2015FINALA4printableversion.pdf.

8 Ellis G, Whitehead MA, Robinson D, O'Neill D, Langhorne P. Comprehensive geriatric assessment for older adults admitted to hospital: a systematic review and meta-analysis. BMJ 2011;356:d6553. doi:10.1136/bmj.d6553 pmid:22034146.

9 Knight J, Nigam Y, Jones A. Effects of bedrest 1: cardiovascular, respiratory and haematological systems[article]. Nurs Times 2009;356:16-20. https://www.nursingtimes. net/clinical-archive/cardiology/effects-of-bedrest-1-cardiovascular-respiratory-andhaematological-systems/5002005.pmid:19548502. 
10 BMA. Primary care in institutions and residential homes. 7 Dec 2016. https://www.bma. org.uk/advice/employment/gp-practices/service-provision/primary-care-in-institutions-andresidential-homes.

11 Brindle D. Nursing shortages are worst in care homes and agency workers fill the gap. Guardian 3 Jun 2015. https://www.theguardian.com/society/2015/jun/03/nursing-shortagesworst-care-homes-agency-workers-fill-gap.
12 Imison C, Castle-Clarke S, Watson R; Nuffield Trust. Reshaping the workforce to deliver the care patients need. 2016. www.nuffieldtrust.org.uk/sites/files/nuffield/publication/ reshaping_the_workforce_web_0.pdf.

Published by the BMJ Publishing Group Limited. For permission to use (where not already granted under a licence) please go to http://group.bmj.com/group/rights-licensing/ permissions 